\title{
Introduction: Beyond nation states?
}

\section{Maria Jose Casa Nova}

\section{David Smith}

Various populations fall under the umbrella term Roma, which denotes a traditionally nomadic population of Indian origins who, since their arrival in Europe in the $14^{\text {th }}$ century have dispersed all over the continent. With expansion of the EU they are its largest minority group with an approximate population of 12 million around half of whom reside in member states. While the social position of Roma people differs between and within different nation states, on the whole they experience disproportionate levels of poverty, unemployment, poor health and accommodation, low levels of school education; social cultural segregation and multiple discrimination. In 2011 the Fundamental Rights Agency (FRA) conducted the second EU Minorities and Discrimination Survey in 11 member states $^{1}$ which revealed that in the countries surveyed $80 \%$ of Roma live below the at-risk-of poverty threshold; only $34 \%$ of Roma males and $16 \%$ of females over 16 were either employed or self-employed; one-third lived in houses without electricity and Roma children were behind their non-Roma peers on all educational indicators (EUAFR, 2016). Life expectancy is 10-15 years less than the EU27 average and they have an average age of 25.1 compared to an average age of 40.2 . Conversely only $2.7 \%$ of the Roma population are over 65 compared to 17\% of the EU-27 population (FSGHA, 2009). The 2019 FRA Report points to the continuing social disadvantage of the Roma population, noting that: "Roma continue to face discrimination because of their ethnicity in access to education, employment, healthcare and housing", stating that "there has been little change in the social and economic situation of Roma across the EU" (2019, p. $111)$.

The East and Central European regions have long been home to the largest Roma populations, with Turkey the largest at an estimated 2, 270,000 (3.75\% of total population) followed by Romania with 1,850,000 (8.75\% of total population) and Bulgaria with 750,000 (9.74\% of total population) (ERRC, 2014). In the light of evidence detailing abuse of human rights, poverty, racist attacks and widespread discrimination, expansion of the EU in 2004 and again in 2007 has resulted in a significant migration of East and Central European Roma into other member states with four (the UK, Greece, Germany and Italy) having migrant Roma populations in excess of 50,000. It is estimated for example, that up to 200,000 Roma have moved to the UK from other parts of the EU (Brown, Scullion and Martin, 2013) despite their Roma and Gypsy/Traveller counterparts in Western Europe often facing similar levels of relative poverty and discrimination as those in the Balkan region (O'Nions, 2014) and have been subjected to expulsions from Germany, France and Italy in violation of both EU and international human rights law (Council of Europe, 2012). More recently Roma have been the target of a resurgent far-right across much of Europe. In Italy for example the Minister Matteo Salvini has promised to implement a Roma

\footnotetext{
${ }^{1}$ Bulgaria, Czech Republic, Greece, Hungary, Italy, Poland, Portugal, Romania, Slovakia and Spain.
} 
census and to expel all non-Italian Roma noting that "unfortunately we will have to keep the Italian Roma because we can't expel them" (Kirchgaessmer, 2018).

Little attention was paid to the Roma at a European level until the 1990s when, in less than a decade, a whole raft of organisations and institutions had been formed addressing the situation of the Roma. What became known as the 'plight of the Roma' was subject to increasing policy concern while the evolution of the EU impacted on the Roma in several ways: in terms of EU enlargement and political integration; the development of inclusion policies as a reflection of increasing European integration, and the increasing centrality of nondiscrimination in the European fundamental rights agenda (Agarin, 2014). Minority rights had been a key theme in discussions between the EU and candidate countries with the former concerned to maintain political stability in future EU territory, particularly in regions where ethnic relations were tense and there was potential for large scale westward migration, especially of Roma populations (Vermeersch, 2012). Subsequently, the 1993 Copenhagen criteria that set out the political and economic criteria for joining the EU also included 'respect for and protection of minorities' as a prerequisite. Funds were directed to candidate states to assist the social and economic inclusion of Roma with infringement of Roma rights in candidate countries closely monitored and reported upon by the European Commission (McGarry, 2012). Organisations and policy initiatives were introduced in candidate countries to ostensibly assist Roma civil and social advancement, but the lack of definitive criteria in the conditions and inconsistent monitoring meant that states could often evade these duties. Indeed, the ongoing persecution and marginalisation of many Roma and sizeable migrations of those populations out of the A8 and A2 accession countries, is testament to the failure to safeguard their rights or improve their living conditions there (O’Nions, 2012).

In 2005 the Decade for Roma Inclusion was launched by the Open Society Initiative and World Bank to consolidate this growing body of policies and actors within a single Framework and targeted Central and SouthEastern Europe. Within this developing policy arena the EU played a significant role in providing a comprehensive legal and institutional framework for policy coordination, targets for improvement with respect to housing, employment, education and health along with financial resources such as the Structural and Cohesion Fund running from 2007 until 2013 (Rovid, 2011). Critics argued that despite its aims of creating dialogue with Roma communities that the raft of initiatives associated with the Decade for Roma Inclusion remained dominated by Soros funded NGOs that lacked legitimacy in the eyes of those communities with progress further hindered by limited resources and poorly defined targets (Rostas and Ryder, 2012, p. 192). The failure of Western European nations to participate despite many having large Roma populations themselves moreover, served to reinforce the double standards within Europe and to entrench the perception that Roma are an exclusive problem of the Eastern European nations (Bunescu, 2018, p. 55).

In 2011 the European Parliament announced the EU Framework for National Roma Integration Strategies (NRIS). The EU Framework (EUF) is based on the Open Method of Coordination that aims to lift 20 million Europeans out of poverty over the next decade. The NRIS was designed to guide member state's Roma 
Strategies and make funds available to support integration efforts, while placing responsibility in the hands of member states for developing their own NRIS Strategy (Rostas and Ryder, 2012). Each member state has produced national strategies for Roma integration in the core areas of education, housing, health, employment and discrimination with an overarching focus on integrated inclusion by recognising that inclusion in one sphere requires inclusion in the others. From 2014 until 2020 an increased emphasis has been placed on participation, cooperation and capacity building with civil society organisations, social actors and local authorities; on addressing the specific needs of deprived communities and geographical areas and in developing a more robust approach to monitoring outputs and results.

The NRIS is thus the first concerted supranational strategy at European Union level to tackle the high levels of poverty and segregation experienced by Roma populations in all EU countries and has generally been implemented through the policy tools of mainstreaming and anti-discrimination. The European Platform which was formed in 2009 for inter-governmental cooperation and information exchange endorsed a set of Common Principles for Roma Inclusion whereby Roma policies would be mainstreamed with explicit, but not exclusive, targeting of Roma. In practice, this often-meant interventions focused on low income neighbourhoods and 'projects...geared towards 'vulnerable groups', 'groups at the margins of the labour market', 'disadvantaged groups', or 'groups living in deprived areas'... with a clear mention that these groups include the Roma.' (Vademecum, undated, p. 3). This approach raises a number of fundamental questions about the merits or otherwise of targeting versus mainstreaming social integration policies; whether or not certain marginalised groups require additional support and resources to promote equality of opportunity, and what measures are required to ensure that such groups can participate effectively in the same mainstream institutions have themselves played a role in entrenching the social and economic exclusion of Roma in the first place (McGarry and Agarin, 2014).

On $30^{\text {th }}$ August 2017 the European Commission published its mid-term review of the EU Framework. This examines the progress made in each member state in the five core areas based on input from national authorities, civil society and other organisations. To date however there is little systematic and comparative evidence regarding the overall approach and policy mechanisms adopted by different member states. This special edition will provide a critically informed analysis of progress made in meeting the objectives of the NRIS in the context of the mid-term review in each of the national case studies participating in this issue. Each contribution addresses the situation in specific member states and provides an in-depth analysis that contextualises the implementation of the NRIS in terms of each nations' particular historical, political, cultural and socioeconomic context. While it is not possible to include all member states, a balance between different EU regions that encompasses different political systems, welfare regimes and policy mechanisms is included to allow for a global perspective on the progress of the NRIS at the level of the EU and of various member states within this larger framework. 
The Roma are at the intersection of several contemporary academic and policy issues surrounding cultural and social exclusion, segregation and marginalisation; discrimination, racism and the appropriate policy and legislative responses as well as the position of minority groups in a Europe witnessing the rise of populist right wing and nationalist political and social movements. Roma migration from east and central to western Europe meanwhile has been a key element in stoking anti-EU rhetoric around A8 and A2 accession in the latter nations, and has been central to debates surrounding welfare tourism, freedom of movement and citizenship rights (Smith, 2016). This special edition therefore is relevant to an interdisciplinary readership and to anybody concerned with minority rights and integration and with the construction of more equitable societies.

\section{The National Case Studies}

Kimmo Granqvists' comparative study of Sweden and Finland - two nations with a long and intertwined history and examples of Nordic 'welfare-capitalist' societies' based around principles of universality and egalitarianism - adopts a historical view. This allows the author to highlight the divergent approaches taken by the two nations in the development and evolution of institutions, processes and practices towards their respective Roma minorities. In Sweden there was little progress on Roma issues until recognition of their minority status in 2000 and more recently, the forming of the Delegation for Roma Issues which outlined a number of national targets consistent with the aims of the European Union Framework (EUF). In Finland a more extensive array of special bodies, organisations and local working groups have engaged with Roma issues and the country implemented its second National Policy on Roma in 2018 in line with the EUF priorities. Despite progress in raising school attendance and attainment most Finnish Roma remain relatively disadvantaged across the four domains of education, health, housing and employment. In Sweden most Roma remain almost completely excluded at all levels of society with progress in both countries hindered by structural racism; the distance between activists and grassroots community members and the lack of effective political mobilisation among Roma and their supporters, all of which call into question the meritocratic and social democratic principles on which the 'Nordic welfare model' is founded.

Rostas and Kovacs' contribution from Hungary, a nation that has a large Roma minority comprising $8.8 \%$ of the population, outlines the prominent role that country has played since the end of communism in promoting minority rights. This includes implementing a system of minority self-government and adopting a programme of National Roma Integration in the mid and late 1990s well before this became an issue for concern at the EU level. Regarding the latter the authors also note that Hungary was instrumental in getting the Roma issue 'Europeanised' and placed firmly on the EU agenda. In 2011 the government approved a package of measures until 2020 to enhance the inclusion of disadvantaged groups including Roma that focused on regional disadvantages and social conditions. Some progress has been made in education (though educational segregation has also increased) but generally there has been little to no improvement and Roma remain 
significantly behind the rest of the population on most common indicators. The authors delineate the three main reasons for this: the failure to learn from previous policy initiatives and the lack of anything new in the EU Framework; policy design at the EU and national level with no new mechanisms to increase Roma participation in the decision making process; insufficient data collection and monitoring procedures and thirdly, the internal political situation with the rise of the far right authoritarian party that has grown increasingly antagonistic of refugees, migrants and minority groups such as the Roma.

With regards to the UK, Lane and Smith discuss the complexity of policy-making and implementation whereby policy is devised by both the central government in London and by the devolved administrations in Scotland, Wales and Northern Ireland. The localism agenda where funds and decision making are enacted at an increasingly localised level adds a further layer of complexity and means that Gypsy, Roma and Traveller (GRT) populations are subjected to different forms of inclusion or exclusion dependent on where they reside in the UK. Of the four nations, only Wales developed a specific NRIS with central government arguing that there was no need to develop a specific NRIS for GRT inclusion, as this is promoted through existing policies such as the Equalities Act 2010. The European Commission's midterm review acknowledged 'modest' progress but also noted that mainstreaming approaches have had a limited impact on GRT communities. Moreover contradictions between three different policy approaches - 'ethnic inclusive' policies such as the 2010 Equality Act; 'post-racial' policies that minimise the existence of racial/ethnic inequalities by focusing on individual 'choice' and 'hyper-ethnic' policies that target particular populations who subsequently experience different rights and entitlements to other citizens. More pressingly the potential consequences of leaving the EU for GRT communities is considered by the authors, of particular relevance here is the implications for UK based migrant Roma's 'Settled Status' and the process for securing their right to reside in the UK.

In Hristova and Milenkova's article on Bulgaria's Roma minority (which represents $4.9 \%$ of the total population), the authors present a diachronic approach to the terminology used to classify the Roma population, as well as public policy measures prior to the elaboration and implementation of the NRIS. Subsequently, the authors discuss the concept of integration and how it is perceived by society and by academics and the role of the Roma population in the development of the Strategy. The authors consider that the 'official' versions of successful Roma integration envisage integration in the light of indicators such as poverty, inequality and social exclusion, and consider that integration is achieved as those indicators decrease. Their analysis of the results of a sociological survey to reflect on the achievement of the NRIS reveals a continuing and significant inequalities between Roma and the rest of society, and also when compared to other populations considered minorities. This suggests that the goals of the Strategy are still far from being achieved along the four axes defined. Particular attention is drawn to health inequalities where the authors note that much of the Roma population does not have health insurance given that it appears linked to labour market participation, which plays a fundamental role in their low levels of health-care access. In turn, and according 
to the data, their mostly precarious relationship with the labour market stems from the lack of education and racist attitudes of many employers in what appears to be a vicious circle.

Alfredo and Veronica's article on the Italian context highlights the conflictual historical relationship between the Roma and non-Roma population and the disconnected and intermittent policies that have characterised government intervention (at national, regional and local level) to address the poverty and structural exclusion of the Italian Roma population. For the authors, the NRIS represented a turning point in the way of working politically with the Roma people who represents $0.25 \%$ of the country's population (about $120-180,000$ persons). With the Strategy, the Roma population ceased to be invisible as "political subjects" but became part of it although this participation did not go, mostly, beyond rhetoric. According to the authors, the Strategy's actual impact on Roma living conditions is still minimal, due to weaknesses in the programme's document, the lack of funds for its implementation and the prevalence of xenophobic and racist attitudes towards Roma in Italian society. Furthermore, the cohesive policy advocated by the National Strategy did not correspond to a homogenisation in its implementation at regional and local level, with poor coordination at the national level and, subsequently wide variations in implementation at local levels. At the same time that they consider that the implementation of the Strategy is not being successfully achieved, the authors highlight its importance for the recognition of the situation experienced by the Roma in all of its complexity.

With regards to Portugal, Casa-Nova's article discusses the complexity of the concept of racism and its persistence in the influence of social representations and social practices vis-à-vis the Roma population, as well as the concepts of integration, minority and majority. Based on this theoretical framework, the author reflects on the progress achieved with the implementation of NRIS in Portugal, emphasising the importance of data collection carried out by the Portuguese government (through the High Commissioner for Migration) for characterisation and diagnosis in several of the NRIS axes, namely in the fields of housing and education. Recognising progress in the situation of the Portuguese Roma population, with the elaboration of housing and education policies, it appears however, that this progress is still far from enabling the construction of a situation of parity between the Roma minority and the majority society. In this sense, the article ends by highlighting the need to denaturalise discriminatory discourses and practices that, whether culturally or economically, continue to keep the Roma minority on the margins of society, pointing out the importance of positive discrimination policies in the construction of this path.

\section{Concluding Remarks}

The six articles that are part of this special issue, reflecting on the implementation of the NRIS in seven countries (Sweden, Finland, Hungary, Italy, United Kingdom, Portugal and Bulgaria) show that the national implementation of the NRIS shows some progress, namely at the level of school education (as the 2017 European Commission's own mid-term evaluation shows). However, the NRIS is a long way from significantly narrowing the gap between national Roma and non-Roma populations in the remaining three 
areas of the Strategy: access to the labour market (outside traditional Roma occupations); access to decent housing and access to health conditions. The continuing segregation of Roma from these spheres shows how preconceptions, stereotypes, discrimination and racism continue to play a fundamental role in maintaining poor living conditions. However, in general, the authors consider that the NRIS has at least prompted member states to devise policies that promote an improvement in the living conditions of the Roma population in the four defined areas, which until then had not been achieved. This means that despite the slow pace of change at the grassroots level, the implementation of the NRIS is making (to date) a marginal difference in the lives of Roma people and has forced governments to think about building more cohesive societies from the point of view of extending equal opportunities to their most stigmatised and marginalised populations.

Despite this, it remains true that centuries of discrimination cannot be eradicated in the seven years since implementation of the NRIS and it remains difficult for many Roma to access fundamental human rights due to enduring and widespread anti-Roma racism in its various forms. The EU's Fundamental Rights Agency (FRA) pointed out in a recent report that

\begin{abstract}
"Concrete measures to address anti-Gypsyism and widespread discrimination against Roma are not yet systematically in place across the EU, nor are they a key priority in the national Roma integration strategies and related policies at European, national, regional and local levels. Few national Roma integration strategies address discrimination as a distinct priority. Many Member States' national Roma integration strategies do not explicitly refer to anti-Gypsyism at all. Enhanced efforts to address discrimination and anti-Gypsyism more concretely and systematically are necessary to strengthen the processes of social inclusion and improve integration outcomes" (FRA, 2019, p.118).
\end{abstract}

Socially constructed as "vulnerable" ${ }^{2}$ many of the Roma population continue to live on the margins of societies. At the same time combating anti-Gypsyism without addressing the underlying structural inequalities that frame the lives of Roma and other marginalised and working-class populations can only have limited impact. The combined impacts of industrial and labour market changes, the imposition of neo-liberal policies, welfare reforms and the impact of the 2008 financial crisis have led to increases in horizontal inequalities across the EU (Inchauste and Karver, 2019). Enhancing equality of opportunity and social integration are laudable aims but the question is rarely asked exactly what precisely is it that the NRIS hopes to integrate the Roma into. Addressing discrimination and anti-Gypsyism may soothe liberal consciences but will do little to address the underlying social, economic and political processes that increasingly means

incorporation into the working class equates to incorporation into declining, high poverty neighbourhoods, that have been discarded by the state and populated by the economically inactive (sick, disabled, retired and lone parents); the economically redundant sections of the local working classes; and a heterogeneous mix of migrant and ethnic groups. In their ardour to further the interests of particular 'pet' communities the advocates of identity politics had little to say about the growing inequalities that have led to a decline in the fortunes and life chances of all working-class people regardless of ethnicity (Smith, 2018, p. 204).

\footnotetext{
2 This premise starts from the sociological assumption that no one is born vulnerable, but is socially constructed as such. Vulnerability is, therefore, the result of cultural and social processes and, as such, is historically transformable.
} 
The integration process is still frequently perceived by observers and commentators to equate to assimilation, e.g: becoming more similar to the wider society, adopting the same values, norms of behaviour and lifestyles. From the point of view of this wider society, this is how 'outsiders' become familiar: by the behavioural predictability of sameness, a fundamental condition for becoming "part of"; to belong. But the logic of the integration process has to be different to be successful: to extend the rationality of each to understand the rationality of the other and to make discursive arguments understandable in order to be credible. It is, thus, essential to construct a "peer-to-peer" relationship", where having a voice is not the ability to speak but the ability to be heard. This path has begun to be constructed, but it is still far from being achieved. Politicians, Roma people, governmental and non-governmental organisations, social movements and the general public need to work together to construct this process. Thus, if the NRIS appears as a common policy with the aim of eliminating the poverty and socio-cultural marginalisation of so many Roma, without the political will of each nation-state, embodied in effective measures of social policy and the commitment of the whole society, this common policy will not have the desired effects of moving us towards cohesive societies where integration is for emancipation and not for subordination. This social change requires more than palliative policies; it requires changes in social structures where the underlying economic and societal processes that perpetuates inequalities is rooted.

Emerging evidence indicates that the current catastrophe caused by Covid-19 has been exacerbating racism against the Roma within the European Union (Matache and Bhapha, 2020). Now more than ever it is crucial that each nation-state becomes more vigilant and proactive in combating marginalisation and socio-cultural segregation. It is important to bear in mind that the freedoms provided by democratic regimes cannot lead to accepting or accommodating prejudice and racism in any of its various manifestations. The maturation of democratic systems also involves the exercise of critical vigilance so that humanity, in all its diversity can be enriched based on core values of solidarity and social justice.

The utopia, as a place under construction, will be to transform each society into societies with social integration without attempting ethnic-cultural assimilation and where all human beings have the income to live outside the poverty line. Societies without status subordination (Fraser, 2000) where economic redistribution, cultural recognition and parity of participation in the public sphere constitute the threedimensionalities of justice that Fraser outlines in Scales of Justice (2009). When this happens, we will have achieved the possibility of exercising emancipatory citizenship, with people as agents of "civic courage", a

\footnotetext{
3 "Peer-to-peer" is an expression that can be read in the same way from left to right and from right to left. It is, therefore, the best expression to account for the construction of situations of equality, meaning an equal relationship between human beings. Without oppression and domination. The two sides of the equation equally powerful and equally vulnerable.
} 
collective political actor, taking the course of history in their hands. This is a work of all including social scientists.

\section{References}

Agarin, T. (2014) 'Travelling without moving? Limits of European Governance for Romani Inclusion', Ethnicities, Vol. 14, No. 6, pp. 737-755.

Brown, P; Scullion, L. and Martin, P. (2013) Migrant Roma in the United Kingdom: Population size and experiences of local authorities and partners, University of Salford/ Joseph Rowntree Charitable Trust.

Bunescu, I. (2016) Roma in Europe: The Politics of Collective Identity Formation, London: Routledge.

Council of Europe (2012) Human Rights of Roma and Travellers in Europe, Strasbourg: Council of Europe Publishing.

European Roma Rights Centre (ERRC) (2014) Roma in Europe, available at: http://www.errc.org/resourcecentre-introduction-to-roma-in-europe

European Union Agency for Fundamental Rights (EUAFR) (2016) Second European Union Minorities and Discrimination Survey: Roma - Selected findings, Luxembourg: Publications Office of the European Union. European Union Agency for Fundamental Rights (EUAFR) (2019) Fundamental Rights Report, Luxembourg: Publications Office of the European Union.

Fraser, Nancy (2000). Nuevas reflexiones sobre reconocimiento. New Left Review, 4, pp. 55-68.

Fraser, Nancy (2009). Scales of justice. Reimagining political space in a globalizing world. Cambridge: Polity Fundación Secretariado Gitano Health Area (FSGHA) (2009) Health and the Roma Community, Analysis of the situation in Europe: Bulgaria, Czech Republic, Greece, Portugal, Romania, Slovakia, Spain, available at: http://ec.europa.eu/justice/discrimination/files/roma_health_en.pdf

Inchauste, G. and Karver, J. (2019) Understanding Changes in Inequality in the EU: World Bank Report on the European Union, available at: http://pubdocs.worldbank.org/en/319381520461242480/EU-IG-ReportUnderstanding-changes-in-Inequality.pdf

Kirchgaessner, S. (2018) 'Far-right Italy Minister vows 'action' to expel thousands of Roma', The Guardian, $19^{\text {th }}$ June.

Matache, M. and Bhapha, J. (2020) 'Anti Roma Racism is Spiraling During Covid-19 Pandemic', Health and Huma Rights Journal, April $7^{\text {th }}$, available at: https://www.hhrjournal.org/2020/04/anti-roma-racism-is-spiralingduring-covid-19-pandemic/

Mc Garry, A. (2012) ‘The dilemma of the European Union's Roma Policy', Critical Social Policy, Vol. 32, Issue 1, pp. 126-136.

Mc Garry, A. and Agarin, T. (2014) 'Unpacking the Roma Participation Puzzle: Presence, Voice and Influence, Journal of Ethnic and Migration Studies, Vol. 40, Issue 12, pp. 1972-1990. 
O’Nions, H. (2014) 'Some Europeans are more equal than others', People, Place and Policy, Vol. 8, Issue 1, pp. 4-18.

Rostas, J. and Ryder, A. (2012) 'EU Framework for National Roma Integration Strategies: insights into empowerment and inclusive policy development', in Richardson, J. and Ryder, A. (eds.) Gypsies and Travellers: Empowerment and inclusion in British society, Bristol: Policy Press.

Smith, D. (2016) 'The political context of migration in the UK: the case of Roma Gypsies', in Zakaria, N.; Abdul-Talib, A. and Osman, N. (2016) (eds.) Handbook of Research on the Impacts International Business and Political Affairs on the Global Economy, Pennsylvania, USA: IGI Global.

Smith, D. (2018) 'Roma migration, anti-migrant sentiment and social integration: a case study in South-East England', Local Economy, Vol. 33, No. 2, pp. 187-206.

Vademecum (undated) The 10 Common Basic Principles on Roma Inclusion, available at: https://www.stiftungevz.de/fileadmin/user_upload/EVZ_Uploads/Handlungsfelder/Handeln_fuer_Menschen rechte/Sinti und Roma/Vademecum.pdf

Vermeersch, P. (2012) 'Reframing the Roma: EU Initiatives and the Politics of Reinterpretation', Journal of Ethnic and Migration Studies, Vol. 38, No. 8, pp. 1195-1212. 